\title{
INFLATION AND INCOME INEQUALITY
}

\section{Arkadiusz Sieron*}

\begin{abstract}
The aim of this paper is to examine the relationship between inflation and income inequality. The article is mainly theoretical, but considerations presented are illustrated by relevant empirical data. Based on our analysis, we claim that inflation, which accelerated after the collapse of the Bretton Woods system in 1971, could have contributed to the rise in income inequality in the USA since the 1970s. Our article transcends the simple notion of an inflation tax and focuses on other redistributive mechanisms of inflation (Cantillon effect) as one of the main causes of income inequality.
\end{abstract}

JEL Classification: D31, E31, E51

Keywords: Cantillon effect, income inequality, inflation, redistribution, wealth inequality

\section{Introduction}

The issue of income inequality is attracting a lot of attention at the time of writing, mainly due to Piketty's famous book (2014), which presents rising income inequality as an argument against the free market or as a rationale for more progressive taxes. On the other hand, some economists believe that measured income inequality has been overstated due to imperfect data or that the current pattern of incomes is caused by desirable factors (e.g. Wilkinson, 2009).

In this paper, we offer a different perspective. We acknowledge the fact of rising income inequality in the USA since the 1970s (e.g. OECD, 2011; Atkinson, Piketty, Saez, 2011), ${ }^{1}$ in spite of many difficulties connected with the measurement of income inequality. We consider it as a serious problem which needs to be explained, because there are strong theoretical and empirical reasons why in the free market with stable money the inequality tends to decrease, at least in developed economies (Kuznets, 1955; Williamson, 1985; Saito, 2010).

\footnotetext{
* Arkadiusz Sieron, Institute of Economic Sciences, University of Wroclaw, Wroclaw, Poland (sieron. arkadiusz@gmail.com). The author would like to thank Harry David and anonymous reviewers for helpful comments and suggestions. The article is based on the third chapter of the doctoral dissertation entitled "The Effects of Money Supply Growth from the Perspective of Cantillon Effect" and was partially made possible by a 2014 Summer Fellowship at the Ludwig von Mises Institute, Auburn, Ala. Previous versions of this article were presented at the International Masaryk Conference which took place 15-19 December 2014 in the Czech Republic, and at the 17th International Conference MEKON 2015 which took place 4-5 February 2015 in Ostrava, Czech Republic.

1 However, global inequality was declining in the 1980s and 1990s (Sala-i-Martin, 2006).
} 
The aim of this paper is to examine the relationship between inflation and income inequality. ${ }^{2}$ The article is mainly theoretical, but considerations presented are illustrated by relevant empirical data. Based on our analysis, we claim that inflation, which accelerated after the collapse of the Bretton Woods system in 1971, could have contributed to the rise in income inequality in the USA since the 1970s. Our article transcends the simple notion of an inflation tax and focuses on other redistributive mechanisms of inflation (Cantillon effect) as one of the main causes of income inequality. ${ }^{3}$

The remainder of the paper is organized as follows. Section 2 reviews the literature on the rise in income inequality, especially in the context of inflation. Section 3 examines the data on inflation and income inequality in the USA. Section 4 explains the Cantillon effect and presents some theoretical considerations about the effect of inflation on income inequality. Section 5 concludes.

\section{Literature Review}

The dominant theory seeks causes of increasing income inequality in the USA (and other OECD countries) since the 1970s in skill-biased technical progress, which increases demand for skilled workers and decreases the relative position of unskilled workers (OECD, 2011). This process is considered to be strengthened by globalization, which forces skilled workers to compete with low-wage workers around the world putting downward pressure on wages (Schmitt, 2012), and by unequal access to increasingly important education (e.g. Gregorio, Lee, 2002).

The above factors can undoubtedly affect income inequality. After all, the distribution of income is the final result of the entire complex economic process. However, we would like to point out that those theories of rising income inequality in the USA since the 1970s that refer to skill-biased technological changes and globalization do not explain two facts. First, income inequality was rising in the USA during the 1920s, when globalization was not as strong as today, or was even in reverse (Rossi, 2007). Second, income inequality decreased during some periods since the 1970s, especially during the Great Recession, when technological progress and globalization were not diminishing.

The relationship between inflation and income inequality has only been analysed in a small subset of the literature on income inequality. For example, inflation was

2 In the article, we focus on monetary inflation, as the increase in money supply can entail important redistributive effects even when consumer price inflation remains low. The best example may be the situation when new money enters the economy via the asset market leading to asset price inflation, or even an asset price bubble, and the corresponding changes in income and wealth distribution. Asset price bubbles and crashes prove the importance of money (and credit) supply growth and the Cantillon effect, even in an environment of price stability (Borio and Lowe, 2002). Therefore, for the purpose of this paper, we generally consider "inflation" as an increase in the quantity of money, which results in the tendency toward a rise in prices (Mises, 1949).

3 We focus on income inequality in the paper, i.e. the uneven distribution of annual income within the population; however, we also present some empirical data on wealth inequality, i.e. the unequal distribution of assets within a population, which is a closely related phenomenon to income inequality. 
not practically discussed in the survey conducted by Krueger among professional economists attending a conference at the New York Federal Reserve on causes of the rise in inequality (Krueger, 2012, p. 5). Similarly, income inequality was largely ignored in a discussion of monetary policy (Mersch, 2014). There are only a few papers directly examining the redistributive effects of (unconventional) monetary policy: Bank of England (2012), Dobbs et al. (2013), Saiki, Frost (2014), Adam, Tzamourani (2015), Claeyset et al. (2015). However, they also ignore the Cantillon effect.

The existing literature reaches inconsistent conclusions (Galli, Hoeven, 2001). For example, Romer, Romer (1998) found that high price inflation is correlated with lower income equality. They conduct a cross-country regression that shows that an average 1 per cent rise in inflation is associated with a rise in the Gini coefficient of 0.2 points. Easterly and Fisher (2001) found that high price inflation tends to lower the share of the bottom quintile and the real minimum wage increasing income inequality, and that the poor are more likely than the rich to mention price inflation as a central economic concern. Similarly, several other works - such as Bulir (2001) or Albanesi (2007) - presented evidence of correlating high rates of price inflation with income inequality, poverty, or both.

On the other hand, other empirical evidence (e.g. Heer, Maussner, 2004; Maestri, Roventini, 2012) finds that price inflation actually reduces income inequality. To reconcile these contradictory results, Galli, Hoeven (2001) assume a nonlinear relation between inflation and income distribution showing that the impact of inflation on income inequality depends on the initial price inflation rate. According to them, rising inflation is associated with a decrease in inequality for low initial inflation rates and with an increase for high initial inflation rates. Other studies also posit this nonlinear relationship. For example, Monnin (2014) showed that at low inflation levels, observed income inequality is high, and then it decreases to reach a minimum at an inflation rate of about 13 per cent, and rises as inflation increases beyond this. We may say that there is a consensus that high and variable inflation leads to a rise in income inequality (IMF, 1996, p. 121).

Other economists, such as Bach and Stephenson (1974) and Wilson (1982), similarly found the conclusion that price inflation is good for the rich and bad for the poor, or vice versa, to be simplistic and questionable. Contrarily, they found that inflation redistributes income from the very poor and the very rich, who have less debt, to the middle-income and upper-middle-income groups, who have more debt.

Theoretical works on inflation and income inequality rarely analyse the Cantillon effect. Some economists treat inflation simply as a tax (whether regressive ${ }^{4}$ or progressive) on cash balances, while others focus on whether the inflation is anticipated or unanticipated (e.g. Laidler, Parkin, 1975; Fischer, Modigliani, 1978). We claim that the issue of whether the new money supply is evenly or unevenly distributed is much more important, because an unevenly distributed money supply entails redistributive effects even if the pace of monetary expansion (or even price inflation) is perfectly anticipated.

4 On regressive inflation tax, see e.g. Erosa, Ventura (2002). 
In other words, the literature on the effect of inflation on income inequality largely focuses only on the redistributive channels from wage earners to profit-takers (due to a hypothesized wage lag) and from net creditors to net debtors (e.g. Laidler, Parkin, 1975; Li, Zou, 2002), but ignores the redistribution from late to early recipients of newly created money.

However, Ledoit (2011) and Coibion et al. (2012) did examine the so-called financialsegmentation channel of inflation. They did not refer directly to the Cantillon effect as a possible cause of income inequality; ${ }^{5}$ however, they showed that inflation redistributes wealth towards those agents most connected to financial markets. Similarly, although Wilson (1982) did not mention the Cantillon effect explicitly, he noticed that prices do not rise by the same extent, resulting in an income and wealth redistribution. Finally, Balac (2008) did not refer to the Cantillon effect directly; however, he accepted that "increasing the money supply is tantamount to a tax that penalizes those who see the new money last" (pp. 4-5). He pointed out that banks loan newly created money to the most creditworthy agents, and that one's creditworthiness is a direct function of wealth. In this way he suggested the link between inflation and wealth inequality.

Hülsmann (2013) wrote the most comprehensive article about the relationship between inflation and income and wealth inequality. He showed, in the thirty years before 2001, a marked trend towards an increased concentration of income in highincome households. He noticed a similar, but stronger tendency for wealth leading to a widening wealth gap between the haves and the have-nots. According to him, the cause of the increasing inequality in the USA, as well as the increasing gap between wealth and current monetary incomes, which tempers upward social mobility (the have-nots must work longer to acquire wealth currently held by the haves), is the loose monetary policy conducted by the central bank under the fiat money system.

However, Hülsmann did not elaborate on exactly how inflation affects inequality. Thus, our contribution to the existing literature is a more systematic analysis of the effects of inflation on inequality. Our article transcends the simple notion of an inflation tax and focuses on other redistributive mechanisms of inflation (Cantillon effect) as one of the main causes of income inequality.

\section{Empirical Evidence on Inflation and Income Inequality}

Data show that income inequality in the USA was falling in the deflationary gold standard period during the second half of the 19th century, while it started rising during the WWI. Next, it fell in the deflationary post-war depression, and again rose in the inflationary Roaring Twenties. From a peak just before the 1929 stock market crash until the early 1950 s, inequality declined (except during the WWII), while from the 1950s to the 1970s it was flat or slightly falling (Piketty and Saez, 2003). The situation changed in the 1970s, when the gold standard was abandoned and the pace of monetary inflation accelerated. ${ }^{6}$

$5 \quad$ Moninn (2014) did it; however, he did not elaborate on this point.

6 In the most of the OECD countries income inequalities started rising in the 1980s, although in Israel, the UK, and the United States it started rising in the 1970s (OECD, 2011). 
The Gini Index grew for US households from 0.40 in 1971 to 0.47 in 2006, while the mean-to-median income ratio, which measures the concentration of income among households in the upper tail of the distribution, rose from 1.14 in 1969 to 1.35 in 2007 (Hülsmann, 2013).

Rising wealth inequality accompanied rising income inequality. This should not be a surprise since income inequality is one of the main reasons for wealth inequality. Between 1983 and 2007 in the United States, the net-worth Gini coefficient grew from 0.80 to 0.83 (Wolff, 2010). In that period, the largest relative gains were made by the wealthiest households. Wolff (2010, p. 13) found that "the top 1 per cent saw their average wealth (in 2007 dollars) rise by over 9 million dollars or by 103 per cent. The remaining part of the top quintile experienced increases from 81 to 142 per cent and the fourth quintile by 71 per cent. While the middle quintile gained 50 per cent, the poorest 40 per cent lost 63 per cent!"

Hülsmann (2013) found similar results. The mean-to-median wealth ratio, which measures the concentration of wealth among households in the upper tail of distribution, rose from 3.65 in 1969 to 5.23 in 2007 . The share of total net worth owned by the top 10 per cent also grew from 67.1 per cent in 1989 to 71.5 per cent (Kennickell, 2009).

Although income and wealth generally change in tandem, during the last forty years wealth grew faster than income, leading to a rise in the ratio of mean net worth to mean income from 4.10 in 1969 to 7.93 in 2007 (Hülsmann, 2013). This means that the number of years taken to accumulate a given level of wealth rose substantially, indicating higher inequality between the haves and have-nots.

The rise in income and wealth inequality coincided with a rise in the pace of monetary inflation. Between 1959 and 1971, the monetary base and M1 rose on average by 4.62 per cent and 3.72 per cent yearly, while between 1971, the year in which the gold standard was repudiated, and 2013 they rose on average (geometric mean) by 9.26 per cent and 5.97 per cent yearly (Federal Reserve Bank of St. Louis, 2015). Higher monetary inflation could have caused redistributive effects that outweighed other, equalizing factors, such as rising productivity.

Such a positive correlation existed also in other countries than the United States and during other periods that did not witness skill-biased technological changes or globalization, which most consider the main reasons behind the rise of income and wealth inequality, but which did witness significant monetary inflation.

The Roaring Twenties may be the best example. Between June 30, 1921 and June 30, 1929 the total money supply increased by $\$ 28$ billion, or about 61.8 per cent (Rothbard, 2000 , p. 93). What is extremely important is that new money entered the economy mainly through huge purchases of securities. This caused the stock market bubble and led to significant changes in income and wealth distribution. In a nutshell, this period saw great prosperity for the middle and upper classes, mostly recipients of dividends, which increased their salaries and at the same time the returns on their stock holdings in the larger corporations. However, the relative situation of lower-income recipients, such as wage earners and farmers, worsened (Radice, 1935). This income redistribution is 
partially illustrated by the growing share of the top decile from 40.59 per cent in 1923 to 46.09 per cent in 1928 (Piketty, Saez, 2003).

Similarly, between 1997 and 2000, a time of expansionary monetary policy and a stock market boom, income inequality surged and the Gini Index rose from 0.53 to 0.56 , while from 2003 to 2007, another period of easy money, it again increased, from 0.54 to 0.57 (Wolff, 2010).

Our claim that inflationary booms are responsible for inequality is strengthened by the opposite case: busts. For instance, the top percentile's income share in the United States declined in the post-WWI depression (1916 to 1920), as well as during the Great Depression (1929 to 1932) (Piketty, Saez, 2003). More recently, between 2000 and 2003, the time of a bear market, the Gini Index fell from 0.56 to 0.54 . Similarly, "the Great Recession witnessed a rather sharp contraction in income inequality. The Gini coefficient fell from 0.574 to 0.549 and the share of the top one percent dropped sharply from 21.3 to 17.2 per cent" (Wolff, 2012, p. 15)

It is not a mere coincidence that the relative income of the top 10 per cent peaked just before the great crashes of 1929 and 2008 (Piketty, 2014) and inequality rose during the great bubble eras fueled by monetary inflation, and fell thereafter. All these facts suggest that monetary inflation is, at least partially, responsible for the rising income and wealth inequality during the last 40 years.

\section{Effects of Inflation on Income Inequality}

In the previous section we presented empirical evidence of the relationship between inflation and income inequality. Of course, correlation does not imply causation; however, there are also strong theoretical arguments that inflation may contribute to the rise of income inequality.

First, inflation decreases the real value of social benefits (Yeager, 1997a). Because of imperfect indexation (e.g. due to the fact that the index is the past inflation rate), the nominal value of social benefits lags behind price changes reducing the real income of the beneficiaries. People receiving social benefits generally have low incomes (Romer, Romer, 1998); therefore, inflation contributes to income inequality.

Second, in countries with progressive income taxes, which prevail nowadays, inflation leads to bracket creep (Wilson, 1982). It raises the effective tax rate for people not initially in the highest tax bracket, thus leading to increasing income inequality.

Third, inflation reduces the value of cash and leads to other forms of storage of wealth. Empirical evidence shows the fraction of household wealth held in liquid assets decreases with income and wealth (Kennickel, Starr-McCluer, 1996). Mulligan, Sala-iMartin (2000) found the probability of hedging against inflation by adopting financial technologies is positively related to the level of household income and wealth. Moreover, wealthier people are more able to economize on cash because they face a lower perunit cost of banking services and "lower per unit cost of credit purchases than their low income counterparts since they consume more than low income households" (Erosa, Ventura, 2002, p. 3). 
The above effects are important, ${ }^{7}$ however, we should not forget that the money supply never enters the economy in a uniform way and never affects prices evenly. In reality the money supply is unevenly distributed into the economy, that is, only through certain channels, affecting different prices in a non-uniform way. This effect is called the Cantillon effect, because Richard Cantillon (1775) was the first to describe it, or alternatively the first-round effect or injection effect. Thus, the Cantillon effect is the non-neutral effect of money resulting from the fact that newly created money is neither evenly nor simultaneously distributed among the population. Therefore, the expansion of the money supply affects the structure of relative prices and leads to changes in resource allocation and distribution of income and wealth. It "can hardly be doubted: monetary expansion cannot leave all real quantities and all relative prices the same as they would otherwise have been. New money enters the economy in a particular way and has differential impacts." (Yeager, 1997b, p. 253) Although inflation entails some effects even if it is uniform, the Cantillon effect should be regarded as more central. Indeed, if money were neutral, there would be no need to increase the money supply.

How does this effect operate, and how does it lead to a rise in income inequality? The first main channel of such inflationary redistribution is from the late to the early recipients of newly created money. The first recipients have higher cash balances, while the prices of their purchases have not yet changed. Therefore, they can purchase more goods and services. However, as new money spreads through the economy, prices are bid up, which means that late recipients face higher prices.

This effect may explain why financial markets - which, thanks to credit expansion, are the very first recipient of any new money supply - in virtually all developed countries have grown faster than the real economy for most of the past century. Since 1980, the US financial sector's share in GDP increased at a faster rate (13 basis points per annum) than it did in the prior 30 years (7 basis point per annum) (Greenwood, Scharfstein, 2012). Accordingly, the US financial services industry grew from 4.9 per cent of GDP in 1980 to 7.9 per cent of GDP in 2007, while market capitalization of equities grew from 50 per cent to 141 per cent of GDP (Greenwood, Scharfstein, 2012).

The impact on income inequality seems to be obvious now. The injection of money into the financial sector augments the salaries of people employed in this sector. In 1980, the typical financial services employee earned roughly the same wage as comparable employees in other industries, while in 2006 the typical wage in the financial sector was an average of 70 per cent higher than in the rest of the economy (Greenwood, Scharfstein, 2012). Similarly, in the finance, insurance, and real estate sectors, employment as a share of total private sector employment rose from 6.6 per cent in 1979 to 7.3 per cent in 2005 (Palley, 2007), while the ratio of CEO pay to average worker pay increased from 27 in 1973 to 300 in the year 2000 (Gordon, Dew-Becker, 2005). These facts may confirm the thesis of Piketty, Saez (2003) that the rise of income inequality in the United States

7 They are only the most important effects of uniform inflation. Other effects include distortion of business accounting, menu costs, and changes in the term of trade, which also can increase income inequality. 
since the 1970s has been caused mainly by a surge in top wages, including the wages of financial professionals.

The second distribution channel is credit expansion. That is, the most important way of increasing money supply in the contemporary monetary system may increase inequality because banks prefer to grant loans to the most creditworthy people and firms, while creditworthiness is a function of wealth and the value of collateral.

The third channel is unequal impact of price inflation. An increase in the money supply never entails uniform price inflation (partially because of the unequal distribution of new money). This means that monetary inflation entails redistribution of income from people who buy goods and services at prices increasing faster than prices of the goods and services they sell, to people who sell goods and services at prices increasing faster than the prices of goods and services they buy, or from people who buy more of the goods and services whose prices increase relatively. Food price inflation seems to have the most redistributive effect, because the poor spend a higher share of their consumer basket on food (Wilson, 1982). Piachaud (1978) found that over the whole period 1956-1974, prices of goods bought in the USA by the fifth percentile rose 26 percentage points more than for average income. Hagemann (1982) obtained similar results: over the period $1972 / 3$ to 1982 , prices increased in the USA at a faster pace for lower income households than for those with higher income.

Similarly, monetary inflation entails redistribution of wealth from people whose assets increase more slowly in price as a result of inflation to those whose assets rise more rapidly in price. The crucial fact here is that the richer households typically have greater holdings of inflated financial assets than poorer households. For example, the richest 10 per cent of households in the United States accounted in 2007 for 81 per cent of the total value of stocks (Wolff, 2010). Based on that, it can be argued that quantitative easing, i.e. purchases of financial assets other than short-term government debt instruments by central banks, entails important redistributive effects.

Another channel of redistribution is from creditors to debtors. Some prices cannot be quickly adjusted because they are fixed. This is why creditors, that is, debt-holders, and fixed-salary employees, suffer from inflation at the expense of debtors. The biggest net debtors in the US economy in the 2001 were government and financial sector, while the net creditors were foreigners and the household sector; however, in the 2000s the financial sector became a net creditor, while the household sector became a net debtor (Eichner et al., 2010), although there are significant differences within the sector. According to data, the main losers from inflation in 2001 in the USA were the poor and the rich, while the winners were the middle-class, that possessed the most net debt (Doepke, Schneider, 2005).

To sum up, because the relatively poor spend more money as a percentage of their expenditure on consumer goods and less on financial assets, and more on goods whose prices rises faster, inflation contributes to the rise in income and wealth inequality. The relatively poor lose also as relatively late recipients of new money (where the first recipients are mainly financial sectors), the recipients of social benefits, and as agents 
less able to protect themselves against inflation and with lower creditworthiness. The analysed channels of monetary inflation on income (and wealth) inequality are presented synthetically in the Table 1 .

Table 1 | Channels of Monetary Inflation on Income (and Wealth) Inequality

\begin{tabular}{|l|l|l|l|l|l|l|l|}
\hline \multicolumn{7}{|c|}{ The channels of inflation on income inequality } \\
\hline $\begin{array}{l}\text { Decrease } \\
\text { in real } \\
\text { value } \\
\text { of social } \\
\text { benefits }\end{array}$ & $\begin{array}{l}\text { Bracket } \\
\text { creep }\end{array}$ & $\begin{array}{l}\text { Reduction } \\
\text { in the real } \\
\text { value } \\
\text { of cash }\end{array}$ & $\begin{array}{l}\text { Redistribution } \\
\text { from late to } \\
\text { early recipients } \\
\text { of newly created } \\
\text { money }\end{array}$ & $\begin{array}{l}\text { Credit- } \\
\text { worthi- } \\
\text { ness is } \\
\text { a function } \\
\text { of wealth }\end{array}$ & $\begin{array}{l}\text { The } \\
\text { structure } \\
\text { of expendi- } \\
\text { tures }\end{array}$ & $\begin{array}{l}\text { The } \\
\text { structure } \\
\text { of assets }\end{array}$ & \begin{tabular}{l}
$\begin{array}{l}\text { Redi- } \\
\text { stribution } \\
\text { from credi- } \\
\text { tors to } \\
\text { debtors }\end{array}$ \\
\hline
\end{tabular}
\end{tabular}

Source: Own elaboration

\section{Conclusion}

The distribution of income has always been a central concern of economics. For many years Kuznets's inverted U-shaped curve was the most common explanation of income inequality dynamics. Therefore, although Marx's critique of income inequalities could have been partially justified in his time, it turned out shortly afterward that blue-collar workers were not only much better off in the late nineteenth century, but also that they gained compared to other income earners (Williamson, 1985). However, after a steady decline or holding flat for many years, income inequality in the OECD countries started to rise in the 1970 s leading to the growth of interest in this subject.

There are many explanations of this phenomenon, such as globalization and skillbiased technological changes, but the redistributive impact of inflation has been understated. This is puzzling, taking into consideration the correlation between rising income inequality and the accelerated pace of monetary inflation after the final abandonment of the gold standard. One potential reason for their lacuna may be that mainstream economists focus nowadays on price inflation rather than monetary inflation, and on price (and wage) rigidity rather than the Cantillon effect. In consequence, they consider inflation a regressive tax, or examine only the redistribution from creditors to debtors. Their observations are often very insightful; however, the redistributive effects of inflation are much more complex. This is because the inflationary redistribution of income (and wealth) depends on many things, such as institutional factors, access to new money, the differences in consumption baskets, or the structure of economic agents' assets and liabilities (Laidler, Parkin, 1975). In other words, changes in the relative income (and wealth) position of different groups depend in large measure on movements in relative prices of goods and assets and differences in the composition of ownership of goods and assets. This is why analyses that focus only on one type of redistribution, such as Piketty (2014), who focuses on the redistribution from labour to capital, cannot be fully satisfactory. ${ }^{8}$

$8 \quad$ Piketty's claim is somewhat puzzling taking into consideration his earlier articles (e.g. Piketty, Saez, 2003), in which he wrote that the rising inequality since the 1970s in the United States was in large part caused by a rise in top wages. 
In this paper we have offered a more systematic analysis of the redistributive effects of inflation. We demonstrated that even uniform monetary inflation increases income inequality because lower-income people generally have less ability to protect themselves against inflation than higher-income people. Moreover, they possess a greater part of their wealth in cash and may suffer more due to institutional reasons such as tax-bracket creep or imperfect indexation of social benefits.

In reality, however, the new money supply never enters the economy evenly and prices do not change in a uniform way. This means that monetary inflation always entails redistribution of income and wealth (Cantillon effect). Generally, such redistribution goes from those whose incomes rise more slowly as a result of inflation (i.e. creditors, late recipients of new money, and people whose assets rise more slowly in price in times of inflation and whose purchased goods rise faster) to those whose incomes rise more rapidly (i.e. debtors, early recipients of newly created money, and people whose assets rise more rapidly in price in times of inflation and whose purchased goods rise more slowly). Further, credit expansion, the contemporary mechanism of monetary inflation, lowers interest rates, which additionally benefits debtors and the financial sector. It may be argued that monetary inflation and the Cantillon effect, not the free-market mechanism, led to the growth of the financial sector in developed economies over the past several years, which contributed to the increase in income inequality.

To prove a causal relationship between inflation and inequality, one must show that inflation redistributes from the relatively poor to the relatively rich. We have presented evidence to this effect. The relatively poor lose not only as taxpayers, recipients of social benefits, and agents less able to protect themselves against inflation, but also as relatively late recipients of new money (where the first recipients are mainly financial sectors), consumers (as they spend more money as a percentage of their expenditure on consumer goods and less on assets, and more on goods whose prices rises faster), and asset holders (as they hold fewer financial assets). Although the impact of creditordebtor redistribution on income (and wealth) inequality is ambiguous, the overall effect of inflation on inequality seems to be positive.

This article is by no means exhaustive. However, we believe we have showed both theoretically and empirically how the faster pace of monetary inflation since the 1970s could have caused the rise of income (and wealth) inequality in the United States in the last 40 years. It is not a pure coincidence that the relative income of the top 10 per cent peaked just before the great crashes of 1929 and 2008, and inequality rose during the great economic bubble eras fueled by monetary inflation, and fell thereafter. We do not claim that the increase in the money supply is the only cause of the rise in income inequality; however, the impact of monetary policy should not be neglected. Actually, the existence of the Cantillon effect may be used as an argument against (too) expansionary monetary policy, which could unintentionally lead to income redistribution (and the consequent increase in income inequality), despite the lack of central banks' legitimacy in redistributing income among society. Our article can thus also deepen our understanding of the effects of monetary policy and boom-bust cycles. 


\section{References}

Adam, K., Tzamourani, P. (2015). Distributional Consequences of Asset Price Inflation in the Euro Area. Deutsche Bank. Discussion Paper No. 27.

Albanesi, S. (2007). Inflation and Inequality. Journal of Monetary Economics, 54(4), 1088-1114. https://doi.org/10.1016/j.jmoneco.2006.02.009.

Atkinson, A. B., Piketty T., Saez E. (2011). Top Incomes in the Long Run of History. Journal of Economic Literature, 49(1), 3-71. https://doi.org/10.1257/jel.49.1.3.

Bach, G. L., Stephenson J. B. (1974). Inflation and the Redistribution of Wealth, The Review of Economics and Statistics, 56(1), 1-13. https://doi.org/10.2307/1927521.

Balac, Z. (2008). Monetary Inflation's Effect on Wealth Inequality: An Austrian Analysis. Quarterly Journal of Austrian Economics, 11(1), 1-17. https://doi.org/10.1007/s12113-008-9028-4.

Bank of England (2012). The Distributional Effects of Asset Purchases. Quarterly Bulletin, 52(3), 254-266.

Borio C., Lowe P. (2002). Asset Prices, Financial and Monetary Stability: Exploring the Nexus. Bank for International Settlements. Working Papers No. 114.

Bulir, A. (2001). Income Inequality: Does Inflation Matter? IMF. Staff Papers No.48(1).

Cantillon, Richard [1755](1959). Essay on the Nature of Trade in General, London: Frank Cass and Co. [Retrieved: 2016-01-02] Available at: http://www.econlib.org/library/NPDBooks/ Cantillon/cntNTCover.html

Claeys G., Darvas Z., Leandro A., Walsh T. (2015). The Effects of Ultra-Loose Monetary Policies on Inequality. Bruegel. Policy Contribution No. 9.

Coibion, O., Gorodnichenko, Y., Kueng, L., Silvia J. (2012). Innocent Bystanders? Monetary Policy and Inequality in the U.S. IMF. Working Paper No. WP/12/199.

Dobbs R., Lund S., Koller S., Shwayder A. (2013). QE and Ultra-Low Interest Rates: Distributional Effects and Risks. The McKinsey Global Institute. Discussion Paper.

Doepke, M., Schneider, M. (2005). Real Effects of Inflation through the Redistribution of Nominal Wealth. Federal Reserve Bank of Minneapolis. Research Department Staff Report No. 355.

Easterly W., Fisher, S. (2001). Inflation and the Poor. Journal of Money, Credit and Banking, 33(2), Part 1, 160-178. https://doi.org/10.2307/2673879.

Eichner M. J., Kohn D. L., Palumbo M. G. (2010). Financial Statistics for the United States and the Crisis: What Did They Get Right, What Did They Miss, and How Should They Change? The Federal Reserve Board. Finance and Economics Discussion Series, April.

Erosa, A., Ventura, G. (2002). On Inflation as a Regressive Consumption Tax. Journal of Monetary Economics, 49(4), 761-795. https://doi.org/10.1016/s0304-3932(02)00115-0.

Federal Reserve Bank of St. Louis (2015). Series: St. Louis Monetary Base; M1 Money Stock. Fed Economic Data. [Retrieved: 2015-08-27] Available at: http://research.stlouisfed.org/fred2/ series/AMBSL\#; https://research.stlouisfed.org/fred2/series/M1.

Fischer, S., Modigliani, F. (1978). Towards an Understanding of the Real Effects and Costs of Inflation. NBER. Working Paper Series No. 303.

Galli, R., Hoeven, R. (2001). Is Inflation Bad for Income Inequality: The Importance of the Initial Rate of Inflation. ILO. Employment Paper No. 29.

Gordon, R. J., Dew-Becker I. (2005). Where Did the Productivity Growth Go? Inflation Dynamics and the Distribution of Income. NBER. Working Paper Series No. 11842. 
Greenwood, R., Scharfstein, D. (2012). The Growth of Modern Finance. Social Science Research Network. Working Paper. [Retrieved 2014-11-02] Available at: http://ssrn.com/ abstract $=2162179$

Gregorio, J., Lee, J-W. (2002). Education and Income Inequality: New Evidence from Cross-Country Data. Review of Income and Wealth, 48(3), 395-416. https://doi. org/10.1111/1475-4991.00060.

Hagemann, R. P. (1982). The Variability of Inflation Rates across Households Types. Journal of Money, Credit and Banking, 14(4), part 1, 494-510. https://doi.org/10.2307/1991657.

Heer, B., Maussner, A. (2005). Distributional Effects of Monetary Policies in a New Neoclassical Model with Progressive Income Taxation. Computing in Economics and Finance, 12, 1-26.

Hülsmann, J. G. (2013). Fiat Money and the Distribution of Incomes and Wealth. Document de travail du GRANEM No.2013-02-039.

IMF (1996). World Economic Outlook: The Rise and Fall of Inflation, Washington, D.C.: International Monetary Fund.

Kennickell, A. B., Starr-McCluer, M. (1996). Household Savings and Portfolio Change: Evidence from the 1983-89. Federal Reserve Board of Governors. SCF Panel Finance and Economics Discussion Series No. 18.

Kennickell, A. B. (2009). Ponds and Streams: Wealth and Income in the US, 1989 to 2007, Federal Reserve Board of Governors. Finance and Economics Discussion Series No. 13.

Krueger, A. B. (2012). The Rise and Consequences of Inequality in the United States, Lecture for Center for American Progress in Washington, D.C., January 12, 2012.

Kuznets, S. (1955). Economic Growth and Income Inequality. American Economic Review, 45(1), $1-28$.

Laidler, D., Parkin, M. (1975). Inflation: A Survey. The Economic Journal. 85(345), 741-809.

Ledoit, O. (2011). The Redistributive Effects of Monetary Policy. University of Zurich Department of Economics. Working Paper Series No. 44.

Li, H., Zou, H-F. (2002). Inflation, Growth, and Income Distribution: A Cross-Country Study. Annals of Economics and Finance, 3, 85-101.

Maestri, V., Roventini, A. (2012). Inequality and Macroeconomic Factors: a Time-Series Analysis for a Set of OECD Countries. Laboratory of Economics and Management. Working Paper Series No. 21.

Mersch Y. (2014). Monetary Policy and Economic Inequality. Lecture at Corporate Credit Conference, Zurich, October 17, 2014.

Mises, L. [1949] (1998). Human Action: A Treatise on Economics, The Scholar's Edition, Auburn, Ala.: Ludwig von Mises Institute.

Monnin, P. (2014). Inflation and Income Inequality in Developed Economies. The Centre for Economic Performance. Working Paper No. 1.

Mulligan, C. B., Sala-i-Martin, X. (2000). Extensive Margins and the Demand for Money at Low Interest Rates. Journal of Political Economy, 108(5), 961-991. https://doi. org/10.1086/317676.

OECD (2011). An Overview of Growing Income Inequalities in OECD Countries: Main Findings, Why Inequality Keeps Rising. Paris: Organization for Economic Cooperation and Development.

Palley, T. I. (2007). Financialization: What It Is and Why It Matters. The Levy Economics Institute. Working Paper No. 525. 
Piachaud, D. (1978). Inflation and Income Distribution, in Hirsh, R., Goldthorpe, J.H., eds., The Political Economy of Inflation, Cambridge: Harvard University Press, pp. 88-116.

Pikkety, T., Saez, E. (2003). Income Inequality in the United States, 1913-1998. Quarterly Journal of Economics, 118(1), 1-39.

Pikkety, T. (2014). Capital in the Twenty-First Century, Cambridge MA: Harvard University Press.

Radice, E. A. (1935). Inflation and the Distribution of Income, in Willis, H. P., Chapman, J. M., eds., The Economics of Inflation: The Basis of Contemporary American Monetary Policy, New York: Columbia University Press, pp. 237-267.

Romer, C. D., Romer, D. H. (1998). Monetary Policy and the Well-Being of the Poor. NBER. Working Paper Series No. 6793.

Rossi, Ino, ed., (2007). Frontiers of Globalization Research. Theoretical and Methodological Approaches, New York: Springer.

Rothbard, Murray (2000). America's Great Depression, fifth ed., Auburn, Ala.: Ludwig von Mises Institute.

Saiki, A., Frost, J. (2014). How Does Unconventional Monetary Policy Affect Inequality? Evidence from Japan. De Nederlandsche Bank. Working Paper No. 423.

Schmitt, J. (2012). Economic Development and Inequality in the United States Since 1979: Inequality as Policy, in Traub-Merz, R., ed., Redistribution for Growth? Income Inequality and Economic Recovery, Friedrich-Ebert-Stiftung, Shangai Coordination Office for International Cooperation, pp. 94-101.

Wilkinson, W. (2009). Thinking Clearly about Economic Inequality. Cato Institute. Policy Analysis No. 640 .

Williamson, J. (1985). Did British Capitalism Breed Inequality? Boston: Allen \&Unwin.

Wilson, G. (1982). Inflation: Causes, Consequences and Cures, Bloomington: Indiana University Press.

Wolff, E. N. (2012). Recent Trends in Household Wealth in the United States: Rising Debt and the Middle-Class Squeeze-an Update to 2007. The Levy Economics Institute. Working Paper No. 589.

Wolff, E. N. (2012). The Asset Price Meltdown and the Wealth of the Middle Class. NBER. Working Paper Series No. 18559.

Yeager, L. (1997a). The Costs, Sources, and Control of Inflation, in Yeager, L. The Fluttering Veil: Essays on Monetary Disequilibrium, Indianapolis: Liberty Fund, pp. 33-84.

Yeager, L. (1997b). Injection Effects and Monetary Intermediation, in Yeager, L. The Fluttering Veil: Essays on Monetary Disequilibrium, Indianapolis: Liberty Fund, pp. 253-279. 